This is the submitted version of a paper that was published online in the Journal of Philosophy of Education 25 October 2017

Please consult the published version if you wish to cite this paper.

\title{
Indoctrination and Systems: a reply to Rebecca Taylor
}

John White

UCL Institute of Education

\begin{abstract}
This is a reply to Rebecca Taylor's 2016 JOPE article 'Indoctrination and Social Context: A System-based Approach to Identifying the Threat of Indoctrination and the Responsibilities of Educators'. It agrees with her in going beyond the indoctrinatory role of the individual teacher to include that of whole educational systems, but differs in emphasizing indoctrinatory intention rather than outcome; and in allowing the possibility of indoctrination without individual teachers being indoctrinators at all.
\end{abstract}

This is a response to Rebecca Taylor's stimulating JOPE piece on 'Indoctrination and Social Context: A System-based Approach to Identifying the Threat of Indoctrination and the Responsibilities of Educators'. I applaud her broadening of the topic beyond the activity of a single indoctrinator to include the contribution of other agencies; but I differ from her on the way we might conceive this.

The centrepiece of Taylor's paper is 'the case of Mr Wilson', a teacher in a remote part of Georgia in 1950. In teaching the history of the Civil War, he is 'aware of the importance of teaching students to think critically', and so 'encourages them to ask questions, to come to their own conclusions about the war'. But he is hamstrung because [a] 'the available textbook presents the latter as The War of Northern Aggression', [b] the Georgia School Board fails to respond to his 
request for additional materials, [c] the books he finds in the local library on slavery 'all confirm a picture of slavery as economically efficient and even beneficial to the slaves', and [d] when he brings in his great-great-grandfather to talk to the class about his experiences as a child in the war, he tells them 'about his father and grandfather leaving to fight for their independence, of Yankee soldiers pillaging their homes while the men were away'. The effect of all this on some students who have 'grown up in a community that views the Confederate cause as honorable' is to reinforce this and related beliefs that they already hold close-mindedly.

Taylor wants to say that these students have been indoctrinated. This is because central to her understanding of this concept is that it requires a certain outcome, ie. 'the production or reinforcement of closed-mindedness'. She rejects other analyses that require an intention to produce this result or something like it. This is why $\mathrm{Mr}$ Wilson's intention to open minds rather than close them does not mean that he cannot have been an indoctrinator. Despite his efforts on this front, the fact that, through his teaching activities, some students end up even more close-minded than they had been is enough to pin this label on him.

But Mr Wilson is, on her view, not the only agent in her story engaged in indoctrination. 'In formal systems of education, it is particularly important to consider the responsibility of educational leaders and policy-makers.' The Georgia School Board plays a part here, not only in prescribing a one-sided textbook, but perhaps also in failing to respond to Mr Wilson's request: 'if members of this board received his request, were aware of materials providing other histories of the Civil War and slavery, were aware that preventing access to these materials might lead to CM [closed-mindedness], and chose not to provide them, then they are accountable for contributing to these students' indoctrination.' Taylor also points out that 'these school board members are part of the broader educational system'. She writes that 'we need to consider educational systems holistically, rather than focusing exclusively on individual teachers.' Her indoctrinatory net goes, indeed, even wider. She writes: 'it is only by scrutinising the broader social system in which he teachesincluding the role of other inputs and processes in the surrounding community and the broader educational system in Georgia at the time-that we can understand the role that Mr. Wilson's lessons play in the broader indoctrinatory system in which his students' are 
immersed (my italics).'

While I think Rebecca Taylor is on to something of great importance in claiming that policy-makers and educational systems as a whole can have an indoctrinatory influence, I am more doubtful about what she says about poor Mr Wilson. She holds that although he wants his students to become open-minded, the teaching activities he engages in are partially responsible for making some of the students more closed-minded than they were, and that it is in virtue of this latter fact that he is involved in indoctrination.

I find it hard to make complete sense of Mr Wilson. If his intention is to open minds, why does he use library books likely to reinforce the pro-Confederacy prejudice he must know many of his students possess? Why does he use the services of his ancient relative when he must know that this will promote Confederate sympathies?

His way of teaching seems to me irrational. Taylor sees his shortcoming, rather, as ignorance: she says that 'he appears unaware of the possibility that his teaching could lead to furthering his students' CM'. I find this hard to credit.

It would be helpful to use a more plausible example. Taylor elaborates this one as she does because she wants to detach indoctrination from having the intention to close minds and tie it only to outcome. This is why she gives us a story about a teacher who has quite the opposite intention, but the things he finds himself doing as a teacher have the effect of closing minds. The story is Taylormade to suit her conceptual claim, but lacks plausibility.

This may well cause us to question the conceptual claim. I cannot see how there can be indoctrination without some intention, somewhere, if not to close minds, at least to prevent reflection on something or other. I will leave until later my reasons for preferring 'preventing reflection' to 'closing minds'.

I am assuming that having such an intention is more than having a wish or vague desire to close down thinking. It brings with it appropriate engagement in action. That is why Mr Wilson is so 
unbelievable. If he really intends to open minds, why does he do the things he does?

In her account of the concept of teaching, Taylor follows Passmore and many others in making room for both intention and outcome. She agrees that in one sense (the 'success' sense) of the term, a person cannot have taught someone $\mathrm{X}$ if the learner has not acquired $X$; while in another sense (the 'attempt' sense), the person can be said to have engaged in teaching the learner $X$, even if in the end the learner fails to acquire $\mathrm{X}$. I see no reason why we should not treat the concept of indoctrination in a similar way. Indeed, Taylor herself comes close to this when she writes: 'Say a parent or teacher fully intends to indoctrinate a child, uses all available means to do so, but ultimately fails. Although this can certainly be called attempted indoctrination, it cannot be called a case of successful indoctrination because an indoctrinated person was not produced.' 'Successful indoctrination' is not simply a matter of one's teaching having as its outcome closing minds, as in Mr Wilson's case: the success here is succeeding in one's attempt to do so; and attempting implies having a corresponding intention.

III

The great virtue of Taylor's article lies, as I have said, in highlighting the possible indoctrinatory role of policy-makers and whole education systems. She writes that previous supporters of an 'outcomes' analysis 'have focused narrowly on the dyadic relationship between a single indoctrinator and indoctrinated person, ignoring the social system in which these individuals are embedded.' She also mentions 'the surrounding community' in her description of the 'broader indoctrinatory system' with which she is concerned, having in mind - in the case she describes - the proConfederacy ethos of the local area where Mr Wilson is teaching.

I differ from her on three points.

[1] Are the kinds of community influences that she mentions part of an indoctrinatory system? The issue concerns the taken-for-granted, unquestioned, ideas found within some communities. In the case of Mr Wilson, these are pro-Confederacy ones. Callan and Arena (2009) discuss a similar case, proposed by Beehler (1985) and in fact the 
prototype for Taylor's Mr Wilson, where a well-meaning teacher in Canada's Northwest Territories in 1930 is tasked with teaching about the indigenous population and their relation to the immigrant white population, but is handicapped partly by the white supremacist views of the local citizenry. Callan and Arena write of the 'broader racist societal indoctrination' behind the teacher's efforts.

I would have no problem with labeling as indoctrinators any individuals within either of these communities who act with the intention of preventing others from reflecting on the taken-forgranted ideas in question. Where this intention is absent, I see difficulties. Take an imaginary tribal society of centuries ago where all kinds of traditional notions were handed down from one generation to the next. No one tried to stop people thinking about them: the very notion of doing this was outside the community's world-view. Although the outcome of the handing-down was that everyone believed the notions unreflectively, I would not call this 'indoctrination'. The latter is only one of the ways in which subjects can end up holding beliefs about things about which they do not reflect. This wider category applies to non-human animals as well as to human beings. We might imagine a community of apes who, for genetic influences perhaps supplemented with social-learning ones, all show in their behaviour that they believe that such and such berries are not to be eaten or that baby apes are to be protected. They have not been indoctrinated into having such beliefs; and in this they are like the members of the tribal society. Insofar as the communities in Canada and Georgia simply pass on, unthinkingly, the ideas in which everyone has grown up, they seem closer to tribal members than to participants in an indoctrinatory system.

[2] I have no such reservations about seeing some educational policy makers as engaged in indoctrination, provided they have the relevant intention. Where I differ from Rebecca Taylor is on the role of the teacher in such cases. Her view is that focusing just on the 'dyadic relationship' between indoctrinating teacher and indoctrinated learners ignores the wider social system in which all these people are embedded. She holds, however, that this dyadic relationship is at least necessary for indoctrination to occur. For her it is indeed the central feature of indoctrination: the contribution of outside agencies like policy-makers is secondary. We see this, for instance, in her agreeing with other writers on the topic that indoctrination is a particular type of bad teaching'. For Taylor, indoctrination cannot 
occur except via a teacher's actions in producing or reinforcing a closed mind in their students, provided that one also acknowledges the contribution of a social system beyond this dyad.

My own view is that a teacher's action that produces or reinforces closed-mindedness is not necessary to indoctrination's taking place. To support this, I go back nearly half a century to the last article I published on indoctrination (White 1970). Here I drew on the reallife example from British educational history of Robert Morant, the Permanent Secretary of the Board of Education at the start of the twentieth century. I wrote:

Morant had been worried for some years about the way in which the post-1870 system of elementary education was producing partly through the growing number of 'higher-grade' schools - too many aspirants to white collar jobs. He was impressed, as his Special Report on higher elementary schools in France shows, by the way in which these schools - through their 'practical' curriculum and through the direct influence of the headmaster as vocational counsellor running a school which was in effect, as Morant observed, a 'bureau de placement' - were 'a potent instrument in the hands of farsighted statesmen, for shaping the thoughts as well as the aptitudes of the cleverer children of the working class towards a particular end-the increase and improvement of the manual workers of the community."' After 1900 Morant destroyed the higher-grade schools in England and restricted the curriculum of all children except the very few who went to the new secondary schools, to elementary subjects which did not allow them to develop a critical attitude to their station in life.'..... He wanted to 'shape the thoughts' of working class children towards a particular end: 'the deep, inner meaning of the true function of popular education', he wrote, was that the primary school was 'a means of giving every child a liking and taste for (his) inevitable occupation."

My suggestion in 1970 was that Morant was the indoctrinator in this story, not teachers in his schools. He wanted to shape elementary pupils' thoughts in a certain direction, taking steps via his control of the curriculum to prevent them from reflecting on the implanted or reinforced idea that they were suited only to a life of manual work. (It does not matter for the sake of the argument whether this assessment of Morant is in fact correct, although there does seem to be good evidence for it). 
In the paper, I discuss the scenario - which comes close to Taylor's account - of some teachers in a Morant-remodelled elementary schools 'ruefully surveying the attitudes of their school-leavers and agreeing with each other that they had only succeeded in indoctrinating them with a belief in the inevitability of their humble lot - even though they did not mean to do this.' Although I was tempted to go with this 'outcome'-but-'no-intention' view of indoctrination, I rejected it in the end: in diligently teaching their nature study, or metalwork or housewifery, the teachers were not indoctrinating, I suggested, because they were not taking steps to prevent their students reflecting on the inevitability of their becoming manual workers.

In 2016 I am still inclined to the same conclusion. Take a teacher of carpentry in a Morantian elementary school. He is brilliant at teaching his boys (for boys they then were) to plane, saw, join pieces of wood by screws or dowels, etc. He does not see himself, unlike $\mathrm{Mr}$ Wilson, as in the business of encouraging the pupils to be openminded, not to believe propositions for which no good evidence is provided. He is not teaching a subject like history where critical thinking of this sort is desirable. He is teaching a practical subject where acquiring know-how, not propositional knowledge, is the aim.

Does this mean that he cannot be an indoctrinator? He may well be one if he is not only aware of the Morantian aim behind elementary schools like his, but also approves of it and sees his woodwork classes as helping to instil it. But what if he simply wants to share his own delight in his woodworking craft with his students, yet the more absorbed in it they become, the more - unknown to him - the notion that they are fit only for a blue-collar job colours their view of the world? If, as Taylor claims, indoctrination is a form of bad teaching, it is hard to see what is bad about what he is doing.

If more important to her argument is that he contributes, albeit unintentionally, to closing minds and is to be called an indoctrinator for that reason, I would not go to the wall in defending my alternative, intentionalist view of the concept come what may. People may wish to use the word 'indoctrination' in ways others are unhappy with, and I would not want to deny them this possibility.

But I think a more plausible way of looking at this case is, as I 
suggested in 1970, to see the teacher as an unwitting tool in the hands of those who are indoctrinators in a full-blooded, intentionalist, sense, ie. Morant himself and those who follow in his footsteps. The teacher is as much a victim of the wider system as the students themselves. He may, indeed, be a target of indoctrination himself if those who control the system take steps to prevent him from reflecting on the wider purposes of the system in which he is teaching - eg by denying him access to teacher education that might open his eyes to what is going on.

[3] This leads me to the third way in which my view differs from Taylor's. It concerns the state of mind of the indoctrinated person. Taylor describes this as 'closed-mindedness'. I have not used this term in my own account, talking instead, as in the paragraph above, about 'preventing reflection' eg. on taken-for-granted ideas.

My reason for favouring the latter view can be seen from the Morant case. I take it that there will be widespread agreement that this is about an indoctrinatory system. The Morant in the story wants elementary pupils to accept or be reinforced in the belief that they are only suited to manual work. He takes steps to prevent their reflecting on this thought - by keeping them apart from pupils in secondary-grammar schools who might give them other ideas; by filling their curriculum with subjects that do not promote critical perspectives; perhaps by controlling what goes on in teacher education so that their teachers remain blinkered.

Crucially, none of this implies that the elementary school pupils in fact end up with closed minds. They end up, if the attempted indoctrination is successful, without the thought that they could do anything else than manual work entering their heads. But that does not imply that their minds are closed. We would only know if they were closed if, counterfactually, this thought - that they could do non-manual work - did enter their heads. Who knows what might happen then? If their minds were closed, they would reject it. But how do we know that they would? The idea might set off all kinds of related thoughts at odds with the inevitability of a life of manual work. We should not assume that they are intellectually too limited to pursue such ideas. Many of these elementary pupils may well be agile and quick thinkers. It is quite likely, as a matter of historical fact, that Morant made the moves he did because he knew that many of the 90-plus per cent of the population earmarked for elementary 
schooling were capable of higher things (which is why he killed off the higher-grade schools).

This is important to my debate with Taylor, because her claim is that successful indoctrination cannot take place unless the indoctrinated person ends up with a closed mind. My view is that this is not necessarily the case.

I realize that I have not clinched my case for my understanding of indoctrination against Taylor's alternative. But then I'm not really set on clinching it. As I have said, if she wants to use the term in the 'outcome-only' way she suggests, she is of course free to do so. Yet there may be some reason to prefer the view I have advocated if we are interested in what actually goes on in educational systems. Using the concept in this way may be fruitful in opening our eyes to wider perspectives.

I will briefly illustrate this from contemporary educational policymaking in England. What we might call 'Morant's problem' - how to prevent too many people from aspiring to higher things - has not gone away. Could one aim of present policy be to encourage acceptance of the hierarchical society in which we live with its wellknown injustices, and discourage thought about alternatives?

Here are three possible ways in which this may be happening. Those targeted are, respectively, learners, teachers and people more generally.

[1] Arranging the curriculum so that there is little or no room for students to reflect on the society in which they live.

Especially since 2010, work on core academic disciplines has tended to crowd out other things, including the study of one's own society. Citizenship aims have been excluded from the 2014 official statement on national curriculum aims. Citizenship is still a minor subject of the national curriculum for secondary students, but the syllabus is largely about the formal system of democratic government and illsuited to promote thought about divisions of class and wealth. Academies, which do not have to follow the national curriculum, 
rarely seem to include citizenship studies. The English Baccalaureate, success in which has now become a central way in which schools are rated, covers only a range of academic disciplines, but not citizenship.

Two striking changes in our society over the last century have been its growing secularization and a revolution in attitudes towards sex and sexual relationships. The present government has removed the study of humanism from GCSE and A level criteria and refused to make PSHE and sex education compulsory.

If these policies have been brought in with the deliberate aim of making reflection on social reality more difficult, they constitute an device - in this case, not confusion as in [3] below, but exclusion (of a curriculum area).

[2] Refocusing teacher education more exclusively on the nuts-andbolts of the job at the expense of work opening teachers' minds to the wider horizons of their work.

This began in the 1980s with withdrawal of funding for in-service teacher education and is now a taken-for-granted feature of our schools. It means that teachers are more likely to accept the system in which they are working and be less well placed to introduce students to other perspectives. Working teachers to the bone and leaving them no time to think hasn't helped either.

Again, if this has been a deliberate aim - beyond the more obviously acceptable one of wanting teachers to be better equipped to provide well-managed and stimulating classes, it would seem to be another indoctrinatory device. It would be another form of exclusion, in this case preventing teachers rather than students from accessing alternative perspectives (or at least making this much for difficult for them).

[3] Trying to persuade us all that we no longer have a selective educational system but one that gives everyone an equal opportunity to do the best for themselves.

Since 1988 we have had a common national curriculum, and a common 16+ examination, the GCSE. This looks egalitarian and democratic. Unlike an élitist régime like Morant's, it is inclusive. But 
could this be masking a selective system, with students from more privileged backgrounds more likely to go to schools with good league table results, and have a home background more favourable to the ultra-academic learning that brings exam success?

If this masking exists and is deliberate, it is an indoctrinatory device in my books. Its purpose is to hinder reflection on what is actually going on by leaving people in confusion over this.

These three policies may or may not have the intentions I have put forward as possibilities. Only further investigation of ministerial motives could reveal this; and it is possible that a proneness to conspiracy theories on my part is all that is uncovered in the end. Meanwhile, the jury is out. The fact that these are not obviously dotty claims underlines my main point in adducing them: to support the practical utility of my account of indoctrination over Taylor's. For her, whether indoctrination were involved in any of the three policy activities would depend solely on whether they contributed to closed-mindedness on the part of students, teachers or other people. This would require a massive and methodologically problem-fraught empirical investigation. Even if it could be carried out, what hypothesis would be triggering the research? I see no reason for suggesting either a positive or a negative result: it looks like a totally open issue. The hypotheses in my own example may be refuted in the end; but at least they come readily to mind as possibilities worth following up.

In this paper I have more than once expressed my agreement with Taylor's emphasis on the system-wide nature of indoctrination. I would go further than her in making this, for the most part, its central feature. For her, the individual teacher, as in the case of Mr Wilson, is the main player: system-wide considerations come in around his activities with his students, as contributory factors in producing closed minds. For me, pragmatic reasons suggest that indoctrination is first and foremost policy-driven. Given that, on my view, it involves taking steps to minimize reflection, those operating the levers of power in a whole system are well placed - better placed than individual teachers - to devise manifold and subtle ways of doing so, eg. via confusion or exclusion. Teachers come into indoctrinatory systems only secondarily. Their activities are part of the armoury that indoctrinators running the system deploy. As in our received picture of schooling under a Soviet or Nazi regime, the teachers are 
not lone operators. They are tools of a larger organization.

\section{References}

Beehler, R. (1985) 'The Schools and Indoctrination', Journal of Philosophy of Education, 19.2, pp. 261-272.

Callan, E. and Arena, D. (2009) 'Indoctrination', in: H. Siegel (ed.) Oxford Handbook of Philosophy of Education (Oxford, Oxford University Press).

Taylor, R. (2016) 'Indoctrination and Social Context: A System-based Approach to Identifying the Threat of Indoctrination and the Responsibilities of Educators' Journal of Philosophy of Education

White, J. (1970) 'Indoctrination: reply to I M M Gregory and R G Woods' in Journal of Philosophy of Education 4:1 (formerly Proceedings of the Philosophy of Education Society Vol. IV.) 